IZA DP No. 9524

The Long Walk: Considering the Enduring Spatial and Racial Dimensions of Deprivation

Two Decades after the Fall of Apartheid

Ronelle Burger

Servaas van der Berg

Sarel van der Walt

Derek Yu

November 2015 


\title{
The Long Walk: \\ Considering the Enduring Spatial and \\ Racial Dimensions of Deprivation \\ Two Decades after the Fall of Apartheid
}

\author{
Ronelle Burger \\ University of Stellenbosch
}

Servaas van der Berg

University of Stellenbosch and IZA

Sarel van der Walt

University of Stellenbosch

Derek Yu

University of Stellenbosch

\section{Discussion Paper No. 9524 \\ November 2015}

\author{
IZA \\ P.O. Box 7240 \\ 53072 Bonn \\ Germany \\ Phone: +49-228-3894-0 \\ Fax: +49-228-3894-180 \\ E-mail: iza@iza.org
}

\begin{abstract}
Any opinions expressed here are those of the author(s) and not those of IZA. Research published in this series may include views on policy, but the institute itself takes no institutional policy positions. The IZA research network is committed to the IZA Guiding Principles of Research Integrity.

The Institute for the Study of Labor (IZA) in Bonn is a local and virtual international research center and a place of communication between science, politics and business. IZA is an independent nonprofit organization supported by Deutsche Post Foundation. The center is associated with the University of Bonn and offers a stimulating research environment through its international network, workshops and conferences, data service, project support, research visits and doctoral program. IZA engages in (i) original and internationally competitive research in all fields of labor economics, (ii) development of policy concepts, and (iii) dissemination of research results and concepts to the interested public.
\end{abstract}

IZA Discussion Papers often represent preliminary work and are circulated to encourage discussion. Citation of such a paper should account for its provisional character. A revised version may be available directly from the author. 
IZA Discussion Paper No. 9524

November 2015

\section{ABSTRACT \\ The Long Walk: \\ Considering the Enduring Spatial and Racial Dimensions of Deprivation Two Decades after the Fall of Apartheid}

This study examines the enduring spatial and racial dimensions of poverty and deprivation in South Africa to assess the progress made by the post-apartheid society and state. A multidimensional approach is required to assess progress because it can reflect the reduction in deprivation attributable to the improved affordability and expanded coverage of government services. While there has been previous studies tracking poverty trends over segments of the post-apartheid period, no previous work has considered multi-dimensional deprivation over the two decades following the official fall of apartheid. We adopt the Total Fuzzy and Relative approach proposed by Cheli and Lemmi (1995) to derive a poverty index with nine dimensions of deprivation, including education, employment, dwelling type, overcrowding, access to electricity, water, telephone, sanitation and refuse collection. Our analysis shows that there has been a significant improvement in South African deprivation levels between 1996 and 2011, but it also finds that geography and race continue to play an important role in explaining patterns of deprivation.

JEL Classification: $\quad 132,138$, N97, D31

Keywords: $\quad$ poverty, deprivation, fuzzy sets, South Africa

Corresponding author:

Ronelle Burger

Department of Economics

University of Stellenbosch

Private Bag X1

Stellenbosch 7602

South Africa

E-mail: rburger@sun.ac.za 


\section{Introduction}

Decades of discriminatory policies have cut deep scars across South Africa's social landscape, creating one of the most unequal and polarised societies in the world. During the colonial and apartheid era the government restricted the geographical settlement choices and freedom of movement of black South Africans. These restrictive policies were also accompanied by large regional discrepancies in government spending, entrenching the association between place and poverty.

The resulting strong racial dimension and distinct spatial footprint of poverty have impeded post-apartheid change and mobility by magnifying the social distance between the deprived and the affluent. In South Africa, deprived households are largely black or coloured ${ }^{1}$ and tend to live on the periphery of the cities and towns. The racial divide is further deepened by its association with cultural and language divides. While one often finds that dimensions such as race, income and geography tend to coincide and overlap, such cuts run far deeper in South African society where these divisions were partly engineered by discriminatory policies and legislation.

The article tracks the progress in addressing the legacy of apartheid by describing the inequalities in South African society at four points in time: 1996, 2001, 2007 and 2011. The South African government has invested significant effort in improving equity with the earliest reforms predating the official end of apartheid. The apartheid government even started to equalise social spending by race and area starting in the 1970s. More policy reversals followed in the 1980s and with the official fall of apartheid in 1994, further reforms were introduced. Aiming to redress apartheid inequalities, Nelson Mandela's post-apartheid government reorganised the provincial structures, decentralised the bureaucracy and approved budgetary shifts to favour the weaker and more deprived provinces.

Such policy reforms and budgetary reallocations have radically improved access to key services. The share of individuals with access to electricity has improved from $44.5 \%$ to $74.6 \%$ between 1996 and $2011 .^{2}$ Similarly, access to clean water has increased from $57.4 \%$ to $74.6 \%$, access to pit latrines or flush toilets has improved from $81.9 \%$ to $92.8 \%$, access to formal housing has risen from $63.5 \%$ to $79.8 \%$ and the share of individuals with access to regular refuse removal has increased from $48.1 \%$ to $61.8 \%$ over the same period. Despite these strides ahead, inequality remains a deeply entrenched feature of South Africa's social landscape, with both race and geography still serving as markers of deprivation and poverty. Analysis of the 1996 and 2011 Census also shows sluggish growth in employment has also constrained social mobility, with a relatively modest increase in the employed share of labour market participants from $65.9 \%$ to $70.2 \%$ over this period.

This work contributes to the wider debate on the achievements and shortfalls of the post-apartheid society and state by examining changes in geographical inequality in the fifteen years between 1996 and 2011 using a multidimensional approach to defining and estimating poverty. Conventionally, many of the studies examining changes in poverty in South Africa have focused on money-metric poverty (Van der Berg 2013; Yu 2012; Leibbrandt,

\footnotetext{
${ }^{1}$ Household surveys and censuses ask respondents to self-identify their race as black, coloured, white or Indian. The coloured category refers to an extremely diverse group of people whose mixed heritage attests to decades of intimate contact amongst a range of ethnic groups (Gibson, 2015). Surveys also often provide an "other" category, but it is rarely used. Although collecting information on race is not uncontroversial, there is broad acceptance that such information is required to assess the performance of the post-apartheid state.

2 The estimates in this paragraph are our own estimates.
} 
Woolard, Finn, \& Argent 2010; Van der Berg, Louw \& Yu 2008; Özler 2007; Hoogeveen, \& Özler 2006; Leibbrandt, Poswell, Naidoo \& Welch 2006) with only two recent studies (Bhorat \& Van der Westhuizen 2013 \& Finn, Leibbrandt \& Woolard 2013) considering trends in multi-dimensional poverty. A multi-dimensional index is preferred over a money-metric poverty approach because it can reflect the impact of efforts to expand access to public infrastructure and the introduction of free basic services.

We therefore implement the Totally Fuzzy and Relative approach to estimating poverty proposed by Cheli and Lemmi (1995) and Cerioli and Zani (1990), adapting and updating earlier work by Qizilbash and Clark (2005) published in this journal. Within the suite of multi-dimensional indices, we opt for this approach because it acknowledges the fuzzy, fluid and continuous nature of poverty and objects to the rigidity of a binary line dividing those that are poor from those who are not. Furthermore, it also avoids the criticism of arbitrary weights by using actual prevalence patterns to determine both the relative weighting of the dimensions of deprivations as well as the categories within each dimension.

The methodology and the data are described in the next two sections, followed with a section reporting poverty and deprivation levels by race and geographical area and the conclusion.

\section{The Fuzzy sets approach to poverty}

Over the past two decades, authors such as Alkire and Foster (2011), Ravallion (1996) and Sen (1985) have eloquently and convincingly presented the case for more multi-dimensional work on poverty to complement existing money-metric approaches. These authors outline the shortcomings of conventional money metric approaches in detail, highlighting that monetary measures do not capture deprivation of non-market goods such as free government services, but also that there are many valuable things that money cannot buy such as meaningful and reciprocal relationships, a sense of belonging, human rights, civil liberties, individual self-esteem and empowerment. A money metric measure may also fail to capture the living condition cost of market failures, for instance while some households are able to afford better accommodation they may have to resort to living in shacks because there are no affordable formal houses available. Furthermore, a money-metric approach will miss the contribution of non-market activities such as unpaid care work and farming for own consumption.

While there are strong arguments for opting for multi-dimensional approaches to measuring poverty and deprivation, there are also a number of pitfalls. Many of the dimensions of deprivation that are poorly represented by income and expenditure are difficult to capture in surveys. Data limitations - both in terms of the variables available in data sets but also, more deeply, the question of how well we can translate some of these dimensions into a quantitative measure via self-reported surveys - remain a significant constraint on multi-dimensional approaches.

This means that there is often considerable freedom and discernment for researchers in constructing a multidimensional index. While this opens the approach to the criticism of arbitrariness, it is important to acknowledge that that there are no neutral or objective measures of poverty and that any index - including traditional poverty lines - reflects some inherent judgement on what it means to be poor and what would be an adequate standard of living. Sen highlights that discernment and judgement are vital for constructing poverty indices and measures for 
it requires "a systematic assessment of importance" because "the job of a measure or an index is to distil what is particularly relevant for the purpose" (Sen 1989).

The most common recourse to deflect the criticism of arbitrariness is to opt for a more empirical approach that let the data speak. Examples of this would include qualitative focus groups, principal component analysis, multiple correspondence analysis and also the Totally Fuzzy and Relative approach employed here. The Totally Fuzzy and Relative approach allows us to derive a multidimensional account of deprivation without assigning arbitrary values to the categories within a poverty dimension (e.g. when deciding how we compare the deprivation associated with access to a pit latrine to that of having no toilet) or assigning arbitrary weights to the dimensions of deprivation (e.g. sanitation deprivation vs. lack of access to running water).

This approach is relative and social in how it allocates values and weights, aligning with intuitive ideas about who is considered to deprived and poor in a society. It implies that a specific form of deprivation would be experienced as worse by the individual if fewer people suffered from this type of deprivation. Conversely, deprivation is experienced as less severe when it is more prevalent in a society. For instance, not having running water in your house may be not be experienced as severe if there are many individuals who are in a similar position. In recognition of the relativist and social nature of the prevalence weighting approach and potential for bias in a country that experienced widespread and structural injustice, we assess the assigned weights for alignment with weights derived using analytical approaches and we examine whether any of the dimensions that receive lower than proportional horizontal weights can be considered to be basic needs or core capabilities.

The Totally Fuzzy and Relative method avoids Deaton's criticism of artificial definiteness of poverty lines. He argues that there are few advantages to setting "a sharp line, below which people count and above which they do not" (1997:144). As poverty is an imprecise and amorphous concept, the 'fuzziness' of TFR poverty indices is an important virtue of this approach. Deaton (1997: 144) explains that "perhaps the best poverty line is an infinite one; everyone is poor, but some a good deal more so than others, and the poorer they are, the greater the weight they should receive in measuring welfare and in policy evaluation."

In line with this intuition, the Fuzzy sets approach was originally developed by Zadeh (1965) and later enhanced by Dubois and Prade (1980) to describe 'fuzzy' membership relations. The Fuzzy sets approach is characterised by a membership function that acknowledges fuzziness of most memberships and associations. If $\mathrm{P}$ is defined to be the fuzzy subset of the deprived or poor, these membership functions will capture the degree to which the individual, the household or the subset of the population belongs to $\mathrm{P}$, as outlined earlier, with a zero value denoting non-membership, a value of one indicating complete membership, and all values between zero and one suggesting some degree of membership, with the size of the index value representing the household or individual's degree of membership of the group of poor. The Total Relative and Fuzzy approach maximises the region of "fuzziness" by setting the minimum level (below which an individual or household is definitely a member of the group) to be the very lowest category, while the top category is selected as the maximum (above which an individual or household is definitely not a member of the group). If an individual or household were to fall between these two levels, then the individual or household would partially belong to the group. 
If $\delta\left(x_{i j}\right)$ represents the membership function for the $i^{\text {th }}$ individual or household in dimension $X_{\mathrm{j}}$, then according to the version of the TFR approach by Cheli and Lemmi (1995), the membership function for discrete variables will look as follows:

$$
\delta\left(x_{i j}\right)= \begin{cases}0 & x_{i j}=x_{j}^{(1)} \\ \delta\left(x_{j}^{(\lambda-1)}\right)+\frac{F\left(x_{j}^{(\lambda)}\right)-F\left(x_{j}^{(\lambda-1)}\right)}{1-F\left(x_{j}^{(1)}\right)} \quad \text { if } & \quad x_{i j}=x_{j}^{(\lambda)}, \lambda=2, \ldots, m\end{cases}
$$

where $F\left(x_{j}^{(\lambda)}\right)$ is the cumulative distribution function of $x_{j}^{(\lambda)}$

Cheli and Lemmi's membership function is used to estimate the extent of deprivation an individual suffers in a specific dimension such as for instance sanitation or water. It presupposes a clear ordinal ranking of categories within a dimension of poverty, i.e. that it is preferable to have a flush toilet rather than a pit latrine, but that a pit latrine is again preferable to a bucket toilet. Deprivation in each dimension is estimated as a prevalence score equal to the share of the individuals that belong to both this category and any categories preferable to this one. Those in the top category receive deprivation scores of 0 and they are excluded from cumulative prevalence calculations for all other score estimates. Those in the bottom category receive a deprivation score of 1.

These scores for each of the $k$ deprivation dimension are aggregated into a composite deprivation index by calculating the weighted sum of the individual deprivation dimension scores:

$$
\begin{aligned}
& \delta_{P}\left(x_{i}\right)=\sum_{j=1}^{k} w_{j} \delta\left(x_{i j}\right) \quad \forall i=1, \ldots, n \\
& \text { with } w_{j} \text { denoting the weight of dimension } X_{j} \text { and } \sum_{j=1}^{k} w_{j}=1 .
\end{aligned}
$$

Cerioli and Zani (1990) proposed a weighting system where each dimension's weight is the inverse function of the number of individuals who are deprived in terms of this dimension, a proposal supported by Miceli (1998) on the basis that people tend to feel more deprived when they do not have access to the same goods or services that most others have access to. This line of thought coincides with a relative concept of poverty. It can be implemented as the following weighting function?

$$
w_{j}=\log \left(\frac{1}{\bar{\delta}\left(x_{j}\right)}\right)
$$

\footnotetext{
${ }^{3}$ Filippone, Cheli and D'Agostino (2001) identify two advantages of choosing a logarithmic functional form in this case: it assigns a value of 0 to those dimensions where the whole population falls into the lowest category, i.e. everyone is deprived, and avoids giving too much importance to extremely rare poverty indicators. Note that $w_{j}$ is not defined when $\bar{\delta}\left(x_{j}\right)=0$, i.e. when no person is deprived or poor in dimension $\mathrm{X}_{\mathrm{j}}$. If everybody is non-poor in dimension $X_{j}$, then dimension $X_{j}$ makes no significant contribution to a study of poverty and should, therefore, not be included.
} 
where $\bar{\delta}\left(x_{j}\right)=\frac{1}{n} \sum_{i=1}^{n} \delta\left(x_{i j}\right)$

with $\bar{\delta}\left(x_{j}\right)$ representing the average deprivation experienced in dimension $X_{j}$.

To distinguish the two sets of weights that the TFR method calculates, the dimension weights (comparing dimensions such as for instance housing vs. sanitation) are referred to as horizontal weights, while the comparison within a dimension across categories (e.g. pit latrines vs flush latrines within the sanitation dimension) are called vertical weights.

\section{Data}

The analysis utilises the 10 per cent samples of the censuses of 1996, 2001 and 2011 as well as the Community Survey of 2007 (CS 2007) conducted by Statistics South Africa. The main benefit of using this series of data is the large sample size that allows more detailed geographical analysis. However, the censuses also have their shortcomings ${ }^{4}$, most notably the small number of variables and the lack of detailed income data.

The 1996, 2001 and 2011 Censuses each took place in October, and a 10\% unit level sample of all households and all persons enumerated in the census was made available for analysis. In the $10 \%$ samples household records were explicitly stratified according to province and District Council. Within each District Council, the records were further stratified by local authority and enumeration area type. Although Census normally takes place every five years, it did not happen in 2006. Therefore, the Community Survey 2007 was undertaken to provide detailed large sample information on development, service delivery and employment between the 2001 and 2011 censuses.

The number of households staying in normal dwellings (i.e. outside institutions) that were included in the four data sets are 846 232, 905 748, 246618 and 1194122 for the Census 1996, the the Census 2001, the Community Survey 2007 and Census 2011 respectively.

\footnotetext{
${ }^{4}$ There are concerns that censuses may not capture the composition and size of the population completely accurately. For instance, post-enumeration surveys revealed an undercount of just over 10 per cent in 1996, and just over 20 per cent in 2001, which have been adjusted in the sample weights. Even after these adjustments, however, demographers have noted some inconsistencies between the censuses, but this should not greatly affect the results of this analysis.
} 


\section{Constructing an index of deprivation}

Table 1 displays the set of dimensions of poverty and their respective categories ranked in increasing order with respect to depth of deprivation. From the set of indicators available in all four our data sets we selected nine indicators: overcrowding, dwelling type, the main source of energy for cooking, water access, telephone access (including access to a mobile phone), refuse removal, sanitation, employment and education. While Clark and Qizilbash's previous work (2002) published in this journal demonstrated that different approaches can lead to setting very different minimum levels, the data available restricts us from considering most of the alternative minimum levels. As our choices are largely aligned with earlier work by Klasen (1997, 2000) and Clark and Qizilbash (2008, 2002), we consider the categorisation of deprivation levels within these nine variables to be uncontroversial and "unlikely to stir much debate" (Klasen, 2000). We deviate from previous categorisations and rankings on three counts - and in each case in an attempt to err on the side of carefulness. For the energy used for cooking dimension of deprivation we have merged the animal dung and wood options into the same category due to the low prevalence of these categories and concern that there is little basis to argue that animal dung should be preferred over wood. We have also collapsed shacks and traditional huts into one category because we argue that it is difficult to argue that inhabiting a traditional dwelling makes one more deprived than living in a shack, confirmed by the disagreement between Clark and Qizilbash (2002) and Klasen (2000) on the ranking. Thirdly, because our analysis is at an individual level and we want to include household members who are not economically active, we opt for a simple three category scale for employment, with the employed as the least deprived, those not participating in the labour market falling in the middle category and with the unemployed ${ }^{5}$ categorised as the poorest and the deprived.

\footnotetext{
${ }^{5}$ South Africa has adopted a narrow definition of unemployment. The difference between the narrow and the broad definition is due to the prevalence of discouraged workseekers, i.e. respondents who say that they want work, but who have not actively sought work over the past four weeks. According to the narrow definition such discouraged workers are classified as not being economically active. In contrast, the broad definition would include them as unemployed and part of the labour force. After the revision of the labour market status derivation methodology in 2008 (with the introduction of QLFS), the discouraged workseekers definition has changed and it is therefore difficult to construct comparable estimates of broad unemployment, thus our deprivation index uses the narrow definition of unemployment.
} 
Table 1: Ranked categories for each deprivation dimension

\begin{tabular}{|c|c|c|c|}
\hline Dimension & Description & Rank & Category \\
\hline \multirow{2}{*}{ Dwelling } & \multirow{2}{*}{ Type of dwelling } & 1 & Formal house/flat or single room/flatlet \\
\hline & & 2 & Traditional hut/shack \\
\hline \multirow{8}{*}{ Crowding } & \multirow{8}{*}{$\begin{array}{l}\text { Number of } \\
\text { persons per room }\end{array}$} & 1 & $(0 ; 0.25]$ \\
\hline & & 2 & $(0.25 ; 0.5]$ \\
\hline & & 3 & $(0.5 ; 0.75]$ \\
\hline & & 4 & $(0.75 ; 1]$ \\
\hline & & 5 & $(1 ; 1.5]$ \\
\hline & & 6 & $(1.5 ; 2]$ \\
\hline & & 7 & $(2 ; 3]$ \\
\hline & & 8 & $(3 ;+\infty)$ \\
\hline \multirow{4}{*}{ Energy } & \multirow{4}{*}{$\begin{array}{l}\text { Energy source } \\
\text { for cooking }\end{array}$} & 1 & Electricity or solar energy \\
\hline & & 2 & Gas \\
\hline & & 3 & Paraffin or coal \\
\hline & & 4 & Wood or animal dung \\
\hline \multirow{5}{*}{ Water } & \multirow{5}{*}{$\begin{array}{l}\text { Type of water } \\
\text { access }\end{array}$} & 1 & Tap in dwelling \\
\hline & & 2 & Tap on premises \\
\hline & & 3 & Public tap or tanker \\
\hline & & 4 & Rainwater tank, borehole or well \\
\hline & & 5 & Dam, river or other \\
\hline \multirow{2}{*}{ Telephone } & \multirow{2}{*}{ Telephone access } & 1 & Landline telephone or mobile phone \\
\hline & & 2 & No landline telephone nor mobile phone \\
\hline \multirow{5}{*}{ Refuse } & \multirow{5}{*}{ Refuse removal } & 1 & Removed by municipality at least once a week \\
\hline & & 2 & Removed by municipality less often \\
\hline & & 3 & Communal refuse dump \\
\hline & & 4 & Own refuse dump \\
\hline & & 5 & No rubbish disposal \\
\hline \multirow{4}{*}{ Sanitation } & \multirow{4}{*}{ Toilet facilities } & 1 & Flush or chemical \\
\hline & & 2 & Pit latrine \\
\hline & & 3 & Bucket latrine \\
\hline & & 4 & No sanitation facilities \\
\hline \multirow{3}{*}{ Employment } & \multirow{3}{*}{$\begin{array}{l}\text { Narrow (Strict) } \\
\text { labour market } \\
\text { status of the } \\
\text { household head }\end{array}$} & 1 & Employed \\
\hline & & 2 & Inactive \\
\hline & & 3 & Unemployed \\
\hline \multirow{5}{*}{ Education } & \multirow{5}{*}{$\begin{array}{l}\text { Education level } \\
\text { of the household } \\
\text { head }\end{array}$} & 1 & Tertiary \\
\hline & & 2 & Completed secondary \\
\hline & & 3 & Incomplete secondary education \\
\hline & & 4 & Incomplete primary education \\
\hline & & 5 & No schooling \\
\hline
\end{tabular}

Table 2 illustrates how horizontal weights are assigned based on the prevalence of deprivation. In all four data sets, the dwelling, energy, refuse and sanitation dimensions received a high share of the weight. The telephone dimension has experienced the greatest change in horizontal weights over this time period, moving from its bottom position in 1996 to the top position in 2011 because a telephone was not considered to be an important form of deprivation and received a low weight in 1996, but that because access to landline and mobile telephones has increased so rapidly, not having access to a telephone was in 2011 considered a more significant form of 
deprivation, with its weighting in the overall deprivation index increasing from $4 \%$ to $21 \%$ (also see Table A.1 in the Appendix).

Table 2: Horizontal weights

\begin{tabular}{|l|c|c|c|c|}
\hline & 1996 & 2001 & 2007 & 2011 \\
\hline Dwelling & 0.136 & 0.146 & 0.131 & 0.132 \\
\hline Crowding & 0.078 & 0.076 & 0.059 & 0.054 \\
\hline Energy & 0.127 & 0.135 & 0.145 & 0.156 \\
\hline Water & 0.133 & 0.101 & 0.106 & 0.086 \\
\hline Telephone & 0.042 & 0.071 & 0.152 & 0.208 \\
\hline Refuse & 0.135 & 0.138 & 0.122 & 0.111 \\
\hline Sanitation & 0.131 & 0.141 & 0.112 & 0.110 \\
\hline Employment & 0.151 & 0.125 & 0.120 & 0.094 \\
\hline Education & 0.068 & 0.069 & 0.052 & 0.048 \\
\hline & 1.000 & 1.000 & 1.000 & 1.000 \\
\hline
\end{tabular}

Table 2 also shows that the derived poverty index is dominated by indicators of public service delivery. The index includes two labour market variables and seven dimensions that linked to service delivery outcomes, of which four - energy, water access, sanitation and refuse removal - are determined directly and entirely by government service delivery.

The relatively low weights allocated to education and employment in 2011 are attributable to the high proportion of South Africans who lack tertiary qualifications and employment respectively. Given the prominence of education and employment as policy priorities, the low weighting for these dimensions reflect the dysfunctional post-apartheid labour market and education system, both of which suffer from widespread and structural problems. In the derived index, this is diluted due to the relative approach's reliance on the prevalence of the deprivation and the implicit assumption that any particular dimension of deprivation is less severe when more individuals are suffering from this form of deprivation. Fortunately, the analysis in the next section is not reliant on the 2011 weights, but uses the 1996 weights where employment still received a higher than proportional weighting. The next section looks at changes over time and we use baseline horizontal weights to ensure that we can meaningfully interpret changes in index values.

\section{Poverty and deprivation by race and area}

This section looks at comparisons of poverty by race and area and also over time, confirming the enduring association between place and poverty. In 1996 there was a notable divide in average deprivation levels in the Western Cape, Gauteng and the Northern Cape (between 0.2 and 0.3) compared to Limpopo and the Eastern Cape (approximately 0.6). These findings are significant in understanding the enduring legacy of apartheid because the Western Cape, Gauteng and the Northern Cape are the only three provinces that did not include significant parts of apartheid era "homelands" assigned for settlement of black South Africans, areas characterised by inadequate public service delivery and a lack of infrastructure during the apartheid period. Noble and Wright (forthcoming in this publication) show that homelands have remained areas that contain much poverty and that they lag behind the urban "townships" (neighbourhoods often on the periphery of cities that were designated for black settlement during the apartheid period). 
The analysis provides encouraging evidence of effective redress in the post-apartheid period. The indices show a sharp fall in deprivation levels across all provinces. ${ }^{6}$ According to Table 3 the aggregate deprivation index level for 1996 of 0.441 is roughly in line with that for the most deprived province (Limpopo) in 2011. Additionally, we see evidence of catching up and a narrowing of the geographical gap. Three of the poorest provinces exceeded the average improvement (0.15) in the index: Eastern Cape (0.20), Limpopo (0.18) and the Free State (0.16). As further evidence one can look at the gap between the least and most deprived province in 1996 and 2011: in 1996 the Western Cape had an average deprivation level of 0.21 while Limpopo's average deprivation was estimated to be 0.62. By 2011 Western Cape deprivation levels had fallen slightly to 0.17 while deprivation in Limpopo was much lower than before at 0.44 , representing a dramatic contraction of the absolute distance between the extremes, at least in terms of this index. In light of the important contribution of service delivery variables to this index, it should also be noted that the preponderence of remote and deep rural areas in provinces such as the Eastern Cape (55\% rural in 2011) and Limpopo ( $82 \%$ rural) may limit the improvement that can realistically be achieved.

Table 3: Average deprivation by province

\begin{tabular}{|l|c|c|c|c|}
\hline & 1996 & 2001 & 2007 & 2011 \\
\hline Western Cape & 0.213 & 0.222 & 0.174 & 0.168 \\
\hline Eastern Cape & 0.610 & 0.567 & 0.488 & 0.408 \\
\hline Northern Cape & 0.326 & 0.316 & 0.247 & 0.275 \\
\hline Free State & 0.410 & 0.409 & 0.292 & 0.251 \\
\hline KwaZulu-Natal & 0.512 & 0.487 & 0.414 & 0.364 \\
\hline North West & 0.479 & 0.451 & 0.371 & 0.330 \\
\hline Gauteng & 0.242 & 0.251 & 0.202 & 0.176 \\
\hline Mpumalanga & 0.466 & 0.458 & 0.359 & 0.337 \\
\hline Limpopo & 0.620 & 0.585 & 0.496 & 0.440 \\
\hline South Africa & 0.441 & 0.418 & 0.339 & 0.292 \\
\hline
\end{tabular}

Figure 1 indeed confirms that poverty and deprivation are in part a rural problem. ${ }^{7}$ However, further analysis shows that the remaining gaps between provinces are not merely due to a higher proportion of rural areas. Rural poverty is deeper in the Eastern Cape, KwaZulu-Natal and Limpopo, where apartheid era underinvestment was at its starkest due to the high concentration of "homeland" areas in these regions. However, part of the differences between the inter-provincial deprivation levels in rural areas may be due to the rural-urban dichotomy obscuring differences in the proportion of remote and deep rural areas included in provinces. Provinces such as Gauteng and the Western Cape have negligible proportions of remote and deeply rural areas ${ }^{8} \mathrm{cf}$. Limpopo and Eastern Cape where a significant proportion of the province's population resides in remote and hard to reach locations.

\footnotetext{
${ }^{7}$ There is a concern that the index may be over-sensitive to rural poverty, due to the prominence of service delivery variables in the index and the lack of variables that can capture access to own produce and other rural livelihood. However, the index does capture the most important dimensions of deprivation and is thus a useful tool in tracking post-apartheid progress, particularly in service delivery.

${ }^{8}$ In Gauteng and Western Cape $92 \%$ and $97 \%$ of residents are classified as urban according to the 2011 Census, in contrast to Limpopo and Eastern Cape where the urban share is $17 \%$ and $45 \%$ respectively.
} 
Figure 1: Cumulative distribution of deprivation by area type, 2011

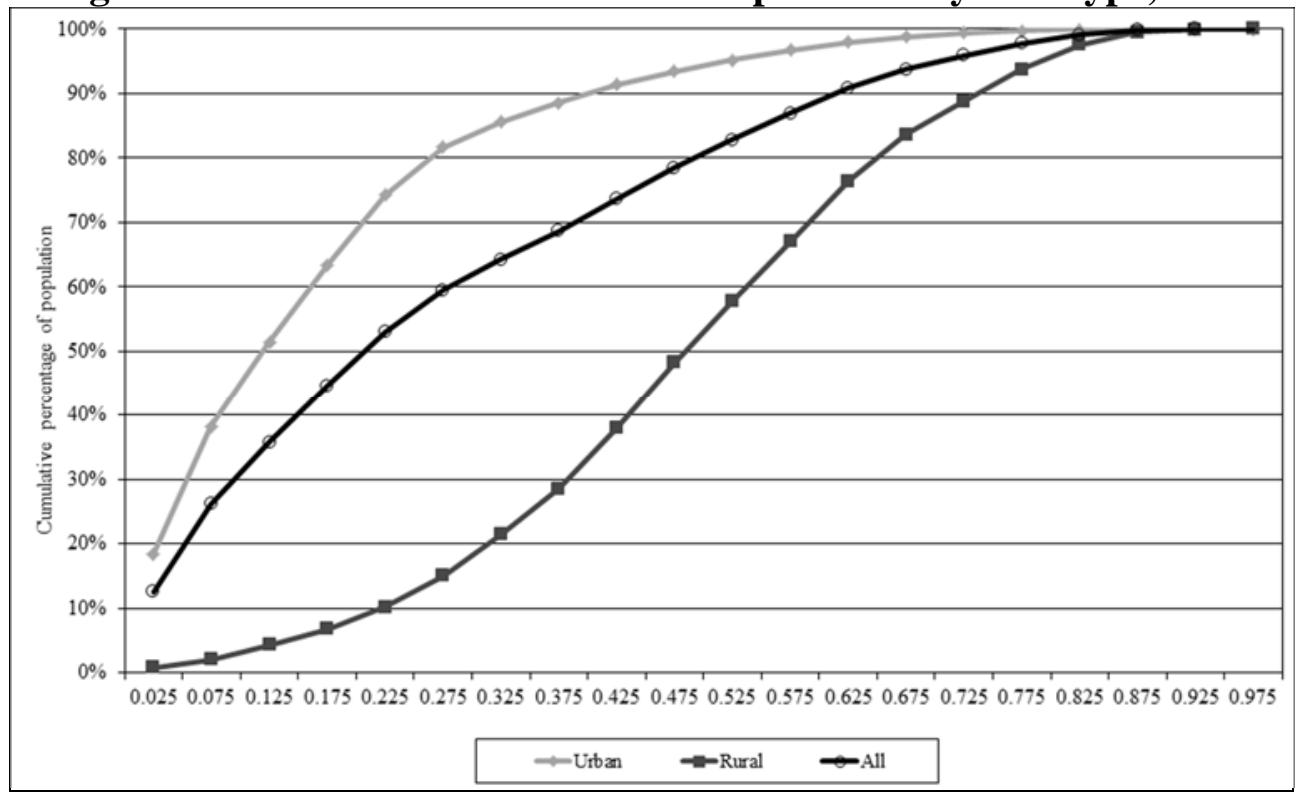

Table 4 shows an improvement across all provinces and all dimensions. There are of course also a few dimensions within provinces that have not shown improvement over time - notably employment in most provinces (the Western Cape, Northern Cape, Free State, KwaZulu-Natal, Gauteng and Mpumalanga), but also dwellings in the Western Cape and refuse collection in the Northern Cape.

The steeper fall in deprivation levels in poor provinces such as Limpopo and the Eastern Cape is driven by improvements across the board. Deprivation has considerably declined in all dimensions, apart from employment and refuse collection. Conversely, progress with deprivation was slower in urban settings and affluent provinces, Indeed, the deterioration of both the dwelling dimension and employment in the Western Cape could be due to pressures of in-migration.

The largest improvement has been in the telephone dimension, largely attributable to expansion in mobile penetration. Due to the relatively low baseline weight of this dimension (only $4 \%$, it will not dominate the index. There are few other notable outliers, except perhaps at the bottom with employment and refuse also showing more sluggish aggregate improvement. Changes in employment deprivation are the result of movement between employment and unemployment, but also in and out of the labour market. Entering the labour market without finding a job represents an increase in measured deprivation. In the post-apartheid period there was a rapid expansion of labour market participation and because movement from not being economically active (not looking for a job) into unemployment (unsuccessfully looking for a job) is seen as an increase in deprivation, rising labour market participation dilutes overall improvement in deprivation.

While there is great variation across provinces in levels of deprivation with respect to sanitation, refuse removal and access to energy, there is remarkable inter-provincial stability in the crowding variable and reasonable stability in education and employment. For all the service delivery variables, there is a sharp divide between levels of deprivation in the Western Cape, Gauteng, the Northern Cape and those in the other provinces. The table also shows that employment deprivation is particularly severe in the Eastern Cape and Limpopo. The Eastern Cape, 
KwaZulu-Natal, Mpumalanga and Limpopo are substantially more deprived in terms of access to energy than other provinces.

Figure 2 considers the two extremes of the racial distribution, comparing deprivation trends for white and black South Africans. It shows that deprivation has diminished for both groups. The vertical axis shows the cumulative percentage of the population that is deprived at any particular level of the index, and its clear declines over time for the black population mean that there is stochastic poverty dominance, i.e. that in each subsequent year the share of black individuals classified as deprived using any threshold has declined. The curves are often indistinguishable for white South Africans, but for black South Africans change have been large and significant. ${ }^{9}$

Figure 2: Cumulative distribution of deprivation by race 1996 - 2011

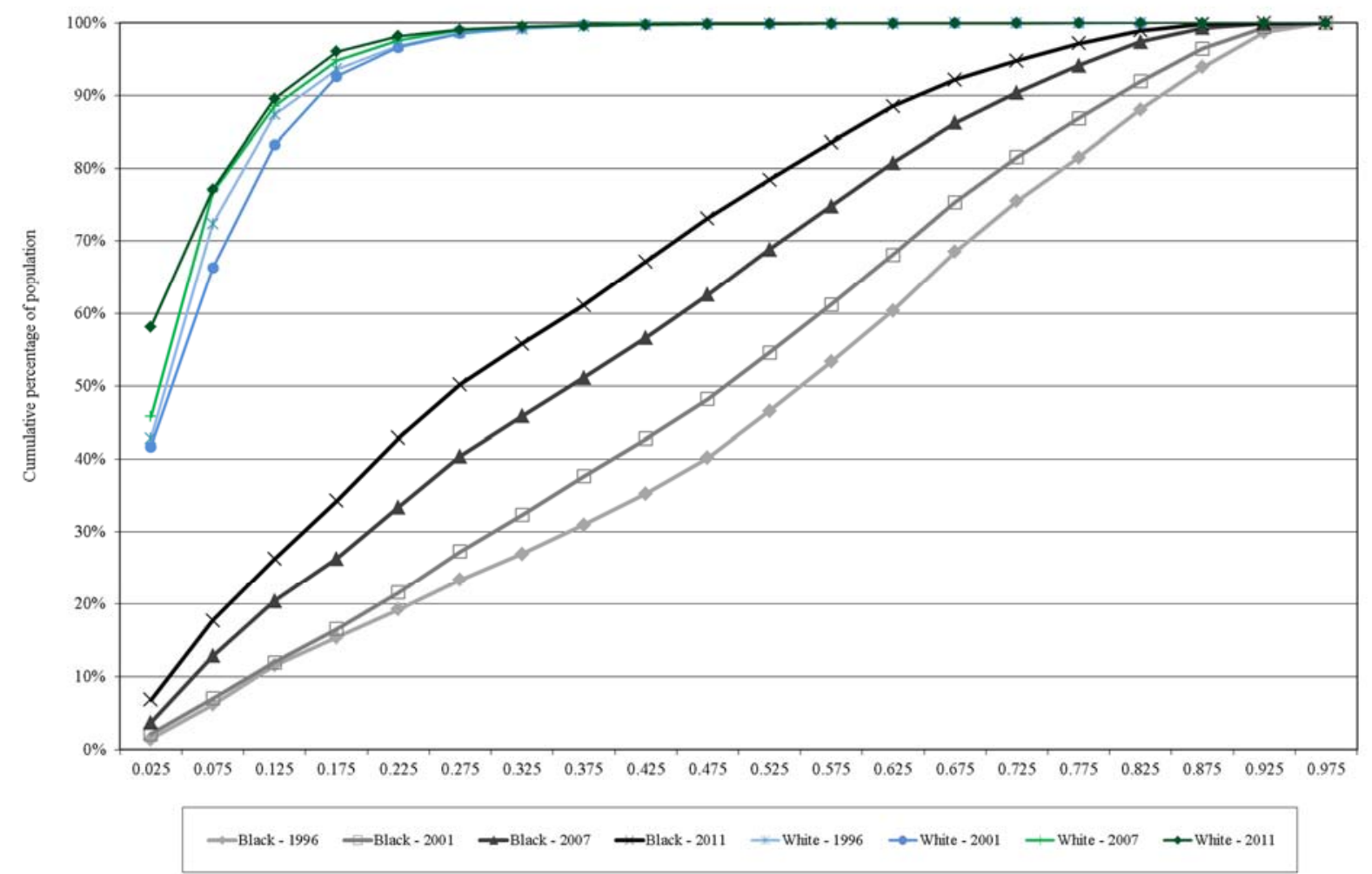

9 Decreases in deprivation are statistically significant at each time period and for each vigintile ( $5 \%$ quantile), except the last vigintile $\left(95^{\text {th }}\right.$ percentile). 
Table 4: Trends in deprivation dimensions by province from 1996 to 2011

\begin{tabular}{|c|c|c|c|c|c|c|c|c|c|c|c|c|c|c|c|c|c|c|c|c|}
\hline & \multicolumn{4}{|c|}{ Dwelling } & \multicolumn{4}{|c|}{ Refuse } & \multicolumn{4}{|c|}{ Crowding } & \multicolumn{4}{|c|}{ Sanitation } & \multicolumn{4}{|c|}{ Water } \\
\hline & 1996 & 2001 & 2007 & 2011 & 1996 & 2001 & 2007 & 2011 & 1996 & 2001 & 2007 & 2011 & 1996 & 2001 & 2007 & 2011 & 1996 & 2001 & 2007 & 2011 \\
\hline WC & 0.197 & 0.203 & 0.170 & 0.205 & 0.097 & 0.082 & 0.048 & 0.057 & 0.491 & 0.501 & 0.523 & 0.432 & 0.124 & 0.129 & 0.071 & 0.072 & 0.130 & 0.170 & 0.105 & 0.127 \\
\hline EC & 0.534 & 0.479 & 0.437 & 0.329 & 0.544 & 0.495 & 0.479 & 0.426 & 0.607 & 0.558 & 0.534 & 0.464 & 0.559 & 0.521 & 0.466 & 0.365 & 0.613 & 0.565 & 0.484 & 0.416 \\
\hline FS & 0.379 & 0.348 & 0.259 & 0.192 & 0.269 & 0.308 & 0.198 & 0.212 & 0.556 & 0.528 & 0.488 & 0.397 & 0.416 & 0.405 & 0.301 & 0.226 & 0.308 & 0.364 & 0.220 & 0.213 \\
\hline KZN & 0.435 & 0.380 & 0.350 & 0.263 & 0.445 & 0.394 & 0.362 & 0.354 & 0.572 & 0.541 & 0.560 & 0.450 & 0.428 & 0.392 & 0.380 & 0.307 & 0.459 & 0.458 & 0.364 & 0.334 \\
\hline NW & 0.310 & 0.282 & 0.278 & 0.242 & 0.489 & 0.485 & 0.389 & 0.383 & 0.554 & 0.499 & 0.518 & 0.410 & 0.472 & 0.442 & 0.386 & 0.353 & 0.426 & 0.436 & 0.349 & 0.331 \\
\hline MPU & 0.347 & 0.294 & 0.216 & 0.156 & 0.469 & 0.473 & 0.414 & 0.431 & 0.540 & 0.515 & 0.500 & 0.391 & 0.435 & 0.422 & 0.382 & 0.361 & 0.363 & 0.418 & 0.299 & 0.315 \\
\hline LIM & 0.365 & 0.270 & 0.146 & 0.103 & 0.711 & 0.693 & 0.667 & 0.612 & 0.599 & 0.567 & 0.530 & 0.421 & 0.639 & 0.614 & 0.574 & 0.508 & 0.543 & 0.547 & 0.485 & 0.435 \\
\hline \multirow[t]{3}{*}{ RSA } & 0.355 & 0.315 & 0.271 & 0.216 & 0.358 & 0.334 & 0.292 & 0.267 & 0.551 & 0.523 & 0.523 & 0.426 & 0.369 & 0.342 & 0.295 & 0.243 & 0.364 & 0.379 & 0.288 & 0.268 \\
\hline & \multicolumn{4}{|c|}{ Energy } & \multicolumn{4}{|c|}{ Employment } & \multicolumn{4}{|c|}{ Education } & \multicolumn{4}{|c|}{ Telephone } & & & & \\
\hline & 1996 & 2001 & 2007 & 2011 & 1996 & 2001 & 2007 & 2011 & 1996 & 2001 & 2007 & 2011 & 1996 & 2001 & 2007 & 2011 & & & & \\
\hline WC & 0.133 & 0.123 & 0.050 & 0.041 & 0.184 & 0.262 & 0.207 & 0.241 & 0.496 & 0.476 & 0.468 & 0.409 & 0.479 & 0.390 & 0.164 & 0.089 & & & & \\
\hline EC & 0.603 & 0.540 & 0.398 & 0.249 & 0.465 & 0.493 & 0.384 & 0.410 & 0.643 & 0.628 & 0.589 & 0.511 & 0.857 & 0.699 & 0.335 & 0.151 & & & & \\
\hline NC & 0.303 & 0.271 & 0.128 & 0.129 & 0.237 & 0.311 & 0.274 & 0.318 & 0.634 & 0.615 & 0.570 & 0.531 & 0.715 & 0.599 & 0.313 & 0.168 & & & & \\
\hline KZN & 0.406 & 0.379 & 0.280 & 0.214 & 0.346 & 0.422 & 0.319 & 0.356 & 0.631 & 0.611 & 0.570 & 0.491 & 0.739 & 0.605 & 0.218 & 0.100 & & & & \\
\hline NW & 0.435 & 0.366 & 0.231 & 0.158 & 0.329 & 0.393 & 0.317 & 0.317 & 0.645 & 0.611 & 0.592 & 0.519 & 0.839 & 0.642 & 0.246 & 0.110 & & & & \\
\hline GAU & 0.158 & 0.152 & 0.104 & 0.076 & 0.218 & 0.307 & 0.223 & 0.244 & 0.498 & 0.465 & 0.445 & 0.373 & 0.586 & 0.449 & 0.151 & 0.050 & & & & \\
\hline MPU & 0.457 & 0.419 & 0.291 & 0.214 & 0.294 & 0.378 & 0.265 & 0.316 & 0.662 & 0.637 & 0.580 & 0.503 & 0.823 & 0.608 & 0.183 & 0.076 & & & & \\
\hline LIM & 0.709 & 0.656 & 0.533 & 0.427 & 0.464 & 0.479 & 0.400 & 0.406 & 0.695 & 0.662 & 0.609 & 0.523 & 0.925 & 0.700 & 0.263 & 0.095 & & & & \\
\hline RSA & 0.378 & 0.339 & 0.233 & 0.164 & 0.317 & 0.382 & 0.292 & 0.313 & 0.596 & 0.568 & 0.533 & 0.456 & 0.728 & 0.571 & 0.218 & 0.090 & & & & \\
\hline
\end{tabular}

Note: WC - Western Cape, EC - Eastern Cape, NC - Northern Cape, FS - Free State, KZN - KwaZulu-Natal, NW - North West, GAU - Gauteng, MPU - Mpumalanga, LIM - Limpopo, RSA - South Africa 
Figure 3 illustrates the racial component of poverty and deprivation by means of a box-and-whisker plot. The enduring impact of race and race-related characteristics is clear from this figure. There is little overlap in the poverty distribution of blacks and whites: the most deprived upper quartile of whites spans a similar range to the least deprived quartile of blacks.

Figure 3: Distribution of deprivation index by population group, 2011

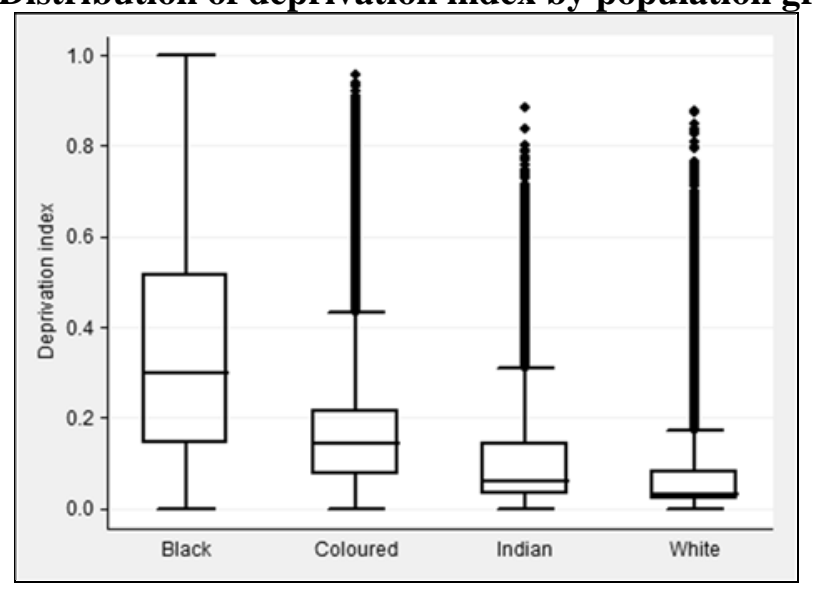

Figure 4 tells a similar story. The cumulative distribution curves for the different population groups in 2011 reveal clear racial poverty dominance. The distribution curve for the black population lies far below that for whites, indicating that at every level of deprivation (represented on the $\mathrm{x}$-axis) a far greater proportion of blacks suffer this level of deprivation or more than white South Africans. Due to the large black share of the population, the curve for the total South African population closely tracks that for black South Africans.

\section{Figure 4: Cumulative distribution of deprivation by race, 2011}

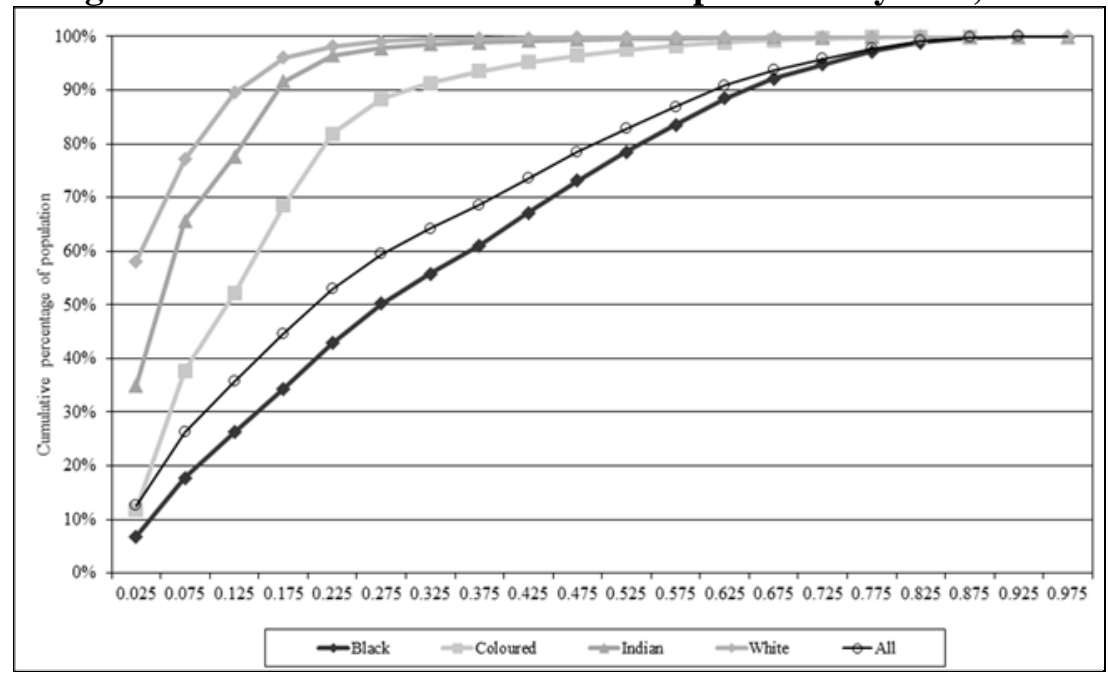

The average level of deprivation for each population group per province is summarised in Table 5 . The deprivation levels of the different races vary per province, but within limited bands, which is indicative of a strong association between race, poverty and geography. Further illustrating this point, a comparison of cumulative distribution curves in Figures A.1 and A.2 in the Appendix shows that there is a bigger provincial variation in deprivation for black South Africans than for their white counterparts. 
Table 5: Average deprivation by population group per province

\begin{tabular}{|c|c|c|c|c|c|c|c|c|}
\hline & \multicolumn{4}{|c|}{ Black } & \multicolumn{4}{|c|}{ Coloured } \\
\hline & 1996 & 2001 & 2007 & 2011 & 1996 & 2001 & 2007 & 2011 \\
\hline Western Cape & 0.396 & 0.367 & 0.258 & 0.234 & 0.199 & 0.201 & 0.161 & 0.157 \\
\hline Eastern Cape & 0.671 & 0.624 & 0.538 & 0.457 & 0.283 & 0.271 & 0.209 & 0.191 \\
\hline Northern Cape & 0.385 & 0.366 & 0.297 & 0.325 & 0.352 & 0.328 & 0.255 & 0.251 \\
\hline Free State & 0.461 & 0.442 & 0.319 & 0.271 & 0.282 & 0.310 & 0.222 & 0.193 \\
\hline KwaZulu-Natal & 0.613 & 0.559 & 0.472 & 0.410 & 0.173 & 0.165 & 0.128 & 0.134 \\
\hline North West & 0.512 & 0.477 & 0.393 & 0.351 & 0.316 & 0.326 & 0.271 & 0.234 \\
\hline Gauteng & 0.312 & 0.306 & 0.247 & 0.205 & 0.165 & 0.172 & 0.135 & 0.123 \\
\hline Mpumalanga & 0.511 & 0.488 & 0.390 & 0.358 & 0.267 & 0.256 & 0.190 & 0.173 \\
\hline Limpopo & 0.634 & 0.597 & 0.507 & 0.451 & 0.368 & 0.311 & 0.225 & 0.196 \\
\hline \multirow[t]{3}{*}{ South Africa } & 0.536 & 0.493 & 0.402 & 0.340 & 0.228 & 0.223 & 0.177 & 0.168 \\
\hline & \multicolumn{4}{|c|}{ Indian } & \multicolumn{4}{|c|}{ White } \\
\hline & 1996 & 2001 & 2007 & 2011 & 1996 & 2001 & 2007 & 2011 \\
\hline Western Cape & 0.097 & 0.108 & 0.095 & 0.087 & 0.067 & 0.073 & 0.064 & 0.056 \\
\hline Eastern Cape & 0.122 & 0.103 & 0.112 & 0.112 & 0.087 & 0.087 & 0.084 & 0.073 \\
\hline Northern Cape & 0.140 & 0.154 & 0.125 & 0.209 & 0.088 & 0.099 & 0.085 & 0.082 \\
\hline Free State & 0.111 & 0.080 & 0.093 & 0.090 & 0.086 & 0.096 & 0.079 & 0.073 \\
\hline KwaZulu-Natal & 0.120 & 0.128 & 0.111 & 0.100 & 0.071 & 0.081 & 0.067 & 0.064 \\
\hline North West & 0.099 & 0.102 & 0.161 & 0.126 & 0.097 & 0.106 & 0.097 & 0.092 \\
\hline Gauteng & 0.092 & 0.098 & 0.079 & 0.066 & 0.071 & 0.077 & 0.063 & 0.053 \\
\hline Mpumalanga & 0.108 & 0.096 & 0.085 & 0.125 & 0.086 & 0.090 & 0.072 & 0.069 \\
\hline Limpopo & 0.185 & 0.098 & 0.103 & 0.117 & 0.116 & 0.112 & 0.096 & 0.091 \\
\hline South Africa & 0.115 & 0.121 & 0.102 & 0.092 & 0.076 & 0.082 & 0.069 & 0.062 \\
\hline
\end{tabular}

Average poverty is worse for households with an unemployed household head than for households with an economically active household head in all provinces except Eastern Cape and KwaZulu-Natal. Moreover, there are substantial gaps in this respect for the least deprived provinces - Western Cape, Gauteng and Northern Cape. Despite the known strong association between education and labour market prospects, Table 6 below shows considerable geographical variation in average poverty within educational groups. This is partly because this is a multi-dimensional index, with substantial representation of service delivery variables. However, a notable share of the residual variation across areas may be attributable to continued geographical differences in labour absorption rates. Due to the latter, there is a stream of job-seeking migrants from poor rural provinces to urban provinces, often leaving older retired household members behind. Due to improvements in educational attainment over time, this cohort tends to have substantially lower levels of educational attainment. Despite the notable differences in deprivation within educational groups, we also see a narrowing of the deprivation gap between provinces especially amongst the less educated. 
Table 6: Average deprivation by educational attainment of household head, per province, 1996, 2001, $2007 \& 2011$

\begin{tabular}{|c|c|c|c|c|c|c|c|c|}
\hline & \multicolumn{4}{|c|}{ No schooling } & \multicolumn{4}{|c|}{ Incomplete primary } \\
\hline & 1996 & 2001 & 2007 & 2011 & 1996 & 2001 & 2007 & 2011 \\
\hline Western Cape & 0.046 & 0.061 & 0.050 & 0.048 & 0.096 & 0.124 & 0.102 & 0.115 \\
\hline Eastern Cape & 0.193 & 0.204 & 0.163 & 0.145 & 0.283 & 0.288 & 0.237 & 0.224 \\
\hline Northern Cape & 0.064 & 0.074 & 0.060 & 0.078 & 0.123 & 0.138 & 0.105 & 0.159 \\
\hline Free State & 0.084 & 0.106 & 0.078 & 0.074 & 0.174 & 0.231 & 0.156 & 0.168 \\
\hline KwaZulu-Natal & 0.089 & 0.122 & 0.103 & 0.099 & 0.189 & 0.222 & 0.188 & 0.215 \\
\hline North West & 0.121 & 0.145 & 0.131 & 0.103 & 0.251 & 0.267 & 0.216 & 0.214 \\
\hline Gauteng & 0.049 & 0.069 & 0.050 & 0.050 & 0.119 & 0.160 & 0.132 & 0.135 \\
\hline Mpumala & 0.114 & 0.151 & 0.110 & 0.115 & 0.246 & 0.275 & 0.205 & 0.241 \\
\hline Limp & 0.260 & 0.270 & 0.212 & 0.189 & 0.432 & 0.418 & 0.362 & 0.343 \\
\hline \multirow[t]{3}{*}{ South Africa } & 0.098 & 0.119 & 0.091 & 0.084 & 0.191 & 0.215 & 0.174 & 0.186 \\
\hline & \multicolumn{4}{|c|}{ Incomplete secondary } & \multicolumn{4}{|c|}{ Completed secondary } \\
\hline & 1996 & 2001 & 2007 & 2011 & 1996 & 2001 & 2007 & 2011 \\
\hline Western Cape & 0.218 & 0.237 & 0.190 & 0.204 & 0.316 & 0.312 & 0.246 & 0.235 \\
\hline Eastern Cape & 0.551 & 0.511 & 0.453 & 0.409 & 0.712 & 0.655 & 0.609 & 0.548 \\
\hline Northern Cape & 0.276 & 0.286 & 0.230 & 0.275 & 0.396 & 0.391 & 0.315 & 0.358 \\
\hline Free State & 0.379 & 0.400 & 0.293 & 0.276 & 0.504 & 0.487 & 0.358 & 0.326 \\
\hline KwaZulu-Natal & 0.408 & 0.407 & 0.355 & 58 & 0.636 & 0.585 & 0.536 & 0.492 \\
\hline North West & 0.439 & 0.429 & 0.345 & 0.340 & 0.556 & 0.524 & 0.441 & 0.411 \\
\hline Gauteng & 0.262 & 0.286 & 0.233 & 0.227 & 0.378 & 0.369 & 0.303 & 0.274 \\
\hline Mpumalanga & 0.407 & 0.423 & 0.335 & 0.350 & 0.532 & 0.512 & 0.431 & 0.412 \\
\hline Limpopo & 0.588 & 0.570 & 0.485 & 0.465 & 0.662 & 0.632 & 0.557 & 0.511 \\
\hline \multirow[t]{3}{*}{ South Africa } & 0.385 & 0.382 & 0.320 & 0.312 & 0.555 & 0.517 & 0.454 & 0.413 \\
\hline & \multicolumn{4}{|c|}{ Tertiary qualification } & & & & \\
\hline & 1996 & 2001 & 2007 & 2011 & & & & \\
\hline Western Cape & 0.373 & 0.367 & 0.270 & 0.272 & & & & \\
\hline Eastern Cape & 0.785 & 0.749 & 0.685 & 0.635 & & & & \\
\hline Northern Cape & 0.472 & 0.443 & 0.381 & 0.411 & & & & \\
\hline Free State & 0.556 & 0.520 & 0.435 & 0.359 & & & & \\
\hline KwaZulu-Natal & 0.738 & 0.697 & 0.646 & 0.587 & & & & \\
\hline North West & 0.601 & 0.573 & 0.511 & 0.467 & & & & \\
\hline Gauteng & 0.407 & 0.400 & 0.344 & 0.309 & & & & \\
\hline Mpumalanga & 0.593 & 0.575 & 0.506 & 0.471 & & & & \\
\hline Limpopo & 0.704 & 0.672 & 0.600 & 0.554 & & & & \\
\hline South Africa & 0.653 & 0.625 & 0.555 & 0.504 & & & & \\
\hline
\end{tabular}

\section{Conclusion}

The paper finds that there has been a remarkable post-apartheid improvement in deprivation levels as measured using the dimensions discussed and that there is evidence of redress taking place. It is encouraging that the observed progress is visible for all provinces and across all dimensions. While aggregate deprivation is still high, deprivation in terms of the dimensions captured here has improved most in the poorest provinces, thosethat were neglected historically. There is a narrowing of the gap between the poorest and most affluent provinces over this time period. 
However, despite progress, the legacy of apartheid remains highly visible in the patterns of deprivation with enduring gaps between black and white; ex-"homeland” provinces and others. White South Africans are unlikely to suffer much deprivation regardless of which provinces they reside in. In contrast, black South Africans tend to experience multiple forms of deprivation and this varies considerably by province.

The selection of a multi-dimensional approach reliant on government services was deliberate, as it allows us to provide a more encompassing view on efforts to overcome the apartheid legacy. However, due to the dominance of service delivery variables the trends shown here present a rosier picture and diverge from the money metric approach. With money-metric poverty analysis, the expansion of service delivery to poorer communities would not be visible. Since 2002 there has been a clear decline in money-metric poverty associated with the introduction and expansion of the child grant (Van der Berg, Louw \& Yu, 2008; Coetzee, 2013). Due to sluggish job growth over this period the labour market has not contributed substantially to poverty alleviation and employment is viewed as a serious concern and policy priority going forward.

Furthermore, it is important to remember that the service delivery indicators do not incorporate the quality of the services, This omission is crucial, particularly in a field such as education where quality differentials are large, or in housing where public housing provision is often of low quality. Services such as refuse removal and sanitation can provide dignity, avoid illness and reduce suffering and inconvenience, but human capital investments are necessary to propel individuals forward and transform the choices and prospects individuals face. We do not report on the quality of education here because there are no adequate proxies for the quality of education available in the data. However, other research has shown that the quality of education in South Africa is far below international benchmarks and remains highly correlated with race, with little improvement observed over the post-apartheid period (Van der Berg et al. 2011). While this analysis provides encouraging signs of post-apartheid transformation and progress towards a more equitable society, we need to be cautious in our optimism because an index that fails to account for the quality of human capital will tend to overestimate the social change that has been achieved.

\section{References}

Alkire, S. \& Foster, J. (2011). Understandings and misunderstandings of multidimensional poverty measurement, Journal of Economic Inequality 9, 289-314.

Bhorat, H. \& Van der Westhuizen, C. (2013). Non-monetary dimensions of well-being in South Africa, 19932004: A post-apartheid dividend? Development Southern Africa 30(3), 295-314.

Cerioli, A \& Zani, S. (1990). A fuzzy approach to the measurement of poverty. In Dagum, C and Zenga, M (Eds.), Income and Wealth Distribution, Inequality and Poverty. (pp 272-284) Berlin: Springer Verlag.

Cheli, B. (1995). Totally fuzzy and relative measures of poverty in a dynamic context: an application to the British Household Panel Survey, 1991-92. ISER Working Paper No 1995-13. Institute for Social and Economic Research, University of Essex, Essex.

Cheli, B \& Lemmi, A. (1995). A totally fuzzy and relative approach to the multidimensional analysis of poverty, Economic Notes 24(1), 115-134.

Clark, D. \& Qizilbash, M. (2008). Core Poverty, Vagueness and Adaptation: A New Methodology and Some Results for South Africa, The Journal of Development Studies 44(4), 519-544.

Clark, D. \& Qizilbash, M. (2005). The capability approach and fuzzy poverty measures: an application to the South African context, Social Indicators Research 74, 103-139. 
Coetzee, M. (2013). Finding the benefits: estimating the impact of the South African child support grant. South African Journal of Economics, 81(3), 427 - 450.

Deaton, A. (1997). The analysis of household surveys: a microeconometric approach to development policy. The John Hopkins University Press: Baltimore.

Dubois, D. \& Prade, H. (1980). Fuzzy Sets and Systems. Academic Press: Boston.

Filippone, A., Cheli, B. \& D’Agostino, A. (2001). Addressing the interpretation and the aggregation problems in totally fuzzy and relative poverty measures. ISER Working Paper No 2001-22. Institute for Social and Economic Research, University of Essex, Essex.

Finn, A., Leibbrandt, M. \& Woolard, I. (2013). What happened to multidimensional poverty in South Africa between 1993 and 2010? SALDRU Working Paper Series Number 99. Cape Town, Southern Africa Labour and Development Research Unit, University of Cape Town.

Gibson, J. L. (2015). Apartheid's Long Shadow: How Racial Divides Distort South Africa's Democracy. Foreign Affairs, March/April 2015:42.

Hoogeveen, J. G. \& Özler, B. (2006). Poverty and inequality in post-apartheid South Africa: 1995-2000. In Bhorat, H. \& Kanbur, R. (eds.). Poverty and policy in post-apartheid South Africa. (pp. 59-94) Human Sciences Research Council: Cape Town.

Leibbrandt, M., Poswell, L., Naidoo, P. \& Welch, M. (2006). Measuring recent changes in South African inequality and poverty using 1996 and 2001 census data. In Bhorat, H. \& Kanbur, R. (ed.), Poverty and Policies in Post-Apartheid South Africa. (pp. 95 - 142). Human Sciences Research Council: Cape Town.

Leibbrandt, M., Woolard, I., Finn, A. \& Argent, J. (2010). Trends in South African income distribution and poverty since the fall of apartheid. OECD Social, Employment and Migration Working Papers No. 101. Organization for Economic Co-operation and Development:Paris.

Klasen, S. (2000). Measuring poverty and deprivation in South Africa, Review of Income and Wealth 46(1), 3358.

Klasen, S. (1997). Poverty, Inequality and Deprivation in South Africa: An Analysis of the 1993 Saldru Survey, Social Indicators Research 41, 51-94.

Miceli, D. (1998). Measuring poverty using fuzzy sets. NATSEM Discussion Paper No. 38. Canberra, National Centre for Social and Economic Modelling. www.natsem.canberra.edu.au/pubs/dps/dp38/dp38.pdf.

Noble, M. \& Wright, G. Forthcoming. Using Indicators of Multiple Deprivation to Demonstrate the Spatial Legacy of Apartheid in South Africa, Social Indicators Research.

Ngwane, A. K., Yadavalli, V. S. S. \& Steffens, F. E. (2001). Poverty in South Africa in 1995: a totally fuzzy and relative approach, Journal for Studies in Economics and Econometrics, 25(1), 77-87.

Özler, B. (2007). Not separate, not equal: poverty in post-apartheid South Africa. Economic Development and Cultural Change, 55(3): 487-529.

Qizilbash, M. (2006). Philosophical Accounts of Vagueness, Fuzzy Poverty Measures and Multidimensionality. In Lemmi, A. \& Betti, G. (eds.) Fuzzy Set Approach to Multidimensional Poverty Measurement. Economic Studies in Inequality, Social Exclusion and Well-Being. Volume 3. (pp 9-28). Springer: New York.

Qizilbash, M. (2002). A note on the measurement of poverty and vulnerability in the South African context, Journal of International Development 14(6), 757-772. 
Ravallion, M. (1996). Issues in measuring and modelling poverty. The Economic Journal, 106 (September): 13281343.

Sen, A. K. (1985). Commodities and capabilities. North-Holland, Amsterdam.

Sen, A. K. (1989). Social progress index: some methodological issues. First Report to UNDP/Latin America Bureau, mimeo.

Van der Berg, S. (2014). Inequality, poverty and prospects for redistribution. Development Southern Africa, 31(2), 197-218.

Van der Berg, S., Louw, M. \& Yu, D. (2008.) Post-Transition Poverty Trends Based On An Alternative Data Source," South African Journal of Economics, Economic Society of South Africa, 76(1), 58-76.

Van der Berg, S., Burger, C., Burger, R., De Vos, M., Du Rand, G., Gustafsson, M., Moses, E., Shepherd, D., Spaull, N., Taylor, S., Van Broekhuizen, H. \& Von Fintel, D. (2011). Low quality education as a poverty trap. University of Stellenbosch: Stellenbosch.

http://www.ekon.sun.ac.za/blog/LowQualityEducationPovertyTrapWorkshop

Van der Berg, S., Louw, M. \& Yu, D. (2008). Post-transition poverty trends based on an alternative data source. South African Journal of Economics, 76(1), 58-76.

Yu, D. (2012). Using household surveys for deriving labour market, poverty and inequality trends in South Africa. $\mathrm{PhD}$ thesis University of Stellenbosch.

Zadeh, L. A. (1965). Fuzzy sets. Information and Control, 8, 338-353. 
Table A.1: Vertical weights per category of deprivation dimension

\begin{tabular}{|c|c|c|c|c|c|c|c|c|c|c|}
\hline \multirow{2}{*}{ Dimension } & \multirow{2}{*}{ Rank } & \multirow{2}{*}{ Category } & \multicolumn{2}{|c|}{1996} & \multicolumn{2}{|c|}{2001} & \multicolumn{2}{|c|}{2007} & \multicolumn{2}{|c|}{2011} \\
\hline & & & {$[\mathrm{I}]$} & {$[\mathrm{II}]$} & {$[\mathrm{I}]$} & {$[\mathrm{II}]$} & {$[\mathrm{I}]$} & {$[\mathrm{III}]$} & {$[\mathrm{I}]$} & [II] \\
\hline \multirow[t]{2}{*}{ Dwelling } & 1 & $\begin{array}{l}\text { Formal house/flat or } \\
\text { single room/flatlet }\end{array}$ & $64.43 \%$ & 0.00 & $68.49 \%$ & 0.00 & $72.92 \%$ & 0.00 & $78.40 \%$ & 0.00 \\
\hline & 2 & Traditional hut/shack & $35.57 \%$ & 1.00 & $31.51 \%$ & 1.00 & $27.08 \%$ & 1.00 & $21.60 \%$ & 1.00 \\
\hline \multirow{8}{*}{ Crowding } & 1 & $(0 ; 0.25]$ & $4.87 \%$ & 0.00 & $6.12 \%$ & 0.00 & $5.45 \%$ & 0.00 & $10.78 \%$ & 0.00 \\
\hline & 2 & $(0.25 ; 0.5]$ & $14.80 \%$ & 0.16 & $16.47 \%$ & 0.18 & $16.96 \%$ & 0.18 & $24.47 \%$ & 0.27 \\
\hline & 3 & $(0.5 ; 0.75]$ & $11.49 \%$ & 0.28 & $11.80 \%$ & 0.30 & $12.90 \%$ & 0.32 & $13.33 \%$ & 0.42 \\
\hline & 4 & $(0.75 ; 1]$ & $23.63 \%$ & 0.52 & $24.69 \%$ & 0.56 & $23.93 \%$ & 0.57 & $23.38 \%$ & 0.69 \\
\hline & 5 & $(1 ; 1.5]$ & $14.52 \%$ & 0.68 & $13.69 \%$ & 0.71 & $13.82 \%$ & 0.72 & $10.52 \%$ & 0.80 \\
\hline & 6 & $(1.5 ; 2]$ & $14.51 \%$ & 0.83 & $13.68 \%$ & 0.86 & $13.29 \%$ & 0.86 & $9.18 \%$ & 0.91 \\
\hline & 7 & $(2 ; 3]$ & $9.89 \%$ & 0.93 & $8.40 \%$ & 0.95 & $8.23 \%$ & 0.94 & $4.91 \%$ & 0.96 \\
\hline & 8 & $(3 ;+\infty)$ & $6.29 \%$ & 1.00 & $5.15 \%$ & 1.00 & $5.41 \%$ & 1.00 & $3.43 \%$ & 1.00 \\
\hline \multirow{4}{*}{ Energy } & 1 & $\begin{array}{l}\text { Electricity or solar } \\
\text { energy }\end{array}$ & $47.33 \%$ & 0.00 & $52.83 \%$ & 0.00 & $67.55 \%$ & 0.00 & $76.25 \%$ & 0.00 \\
\hline & 2 & Gas & $3.35 \%$ & 0.06 & $2.61 \%$ & 0.06 & $2.10 \%$ & 0.06 & $3.59 \%$ & 0.15 \\
\hline & 3 & Paraffin or coal & $26.51 \%$ & 0.57 & $24.98 \%$ & 0.58 & $16.55 \%$ & 0.57 & $9.40 \%$ & 0.55 \\
\hline & 4 & Wood or animal dung & $22.81 \%$ & 1.00 & $19.59 \%$ & 1.00 & $13.80 \%$ & 1.00 & $10.77 \%$ & 1.00 \\
\hline \multirow{5}{*}{ Water } & 1 & Tap in dwelling & $43.65 \%$ & 0.00 & $32.86 \%$ & 0.00 & $48.73 \%$ & 0.00 & $47.76 \%$ & 0.00 \\
\hline & 2 & Tap on premises & $17.27 \%$ & 0.31 & $29.77 \%$ & 0.44 & $22.04 \%$ & 0.43 & $28.19 \%$ & 0.54 \\
\hline & 3 & Public tap or tanker & $21.31 \%$ & 0.68 & $23.67 \%$ & 0.80 & $19.66 \%$ & 0.81 & $17.46 \%$ & 0.87 \\
\hline & 4 & $\begin{array}{l}\text { Rainwater tank, } \\
\text { borehole or well }\end{array}$ & $4.73 \%$ & 0.77 & $4.52 \%$ & 0.86 & $4.13 \%$ & 0.89 & $1.90 \%$ & 0.91 \\
\hline & 5 & Dam, river or other & $13.04 \%$ & 1.00 & $9.18 \%$ & 1.00 & $5.43 \%$ & 1.00 & $4.68 \%$ & 1.00 \\
\hline \multirow[b]{2}{*}{ Telephone } & 1 & $\begin{array}{l}\text { Landline telephone in } \\
\text { dwelling or cellphone }\end{array}$ & $27.03 \%$ & 0.00 & $42.85 \%$ & 0.00 & $78.23 \%$ & 0.00 & $91.02 \%$ & 0.00 \\
\hline & 2 & $\begin{array}{l}\text { No landline telephone } \\
\text { in dwelling and } \\
\text { cellphone }\end{array}$ & $72.97 \%$ & 1.00 & $57.15 \%$ & 1.00 & $21.77 \%$ & 1.00 & $8.98 \%$ & 1.00 \\
\hline \multirow{5}{*}{ Refuse } & 1 & $\begin{array}{l}\text { Removed by } \\
\text { municipality at least } \\
\text { once a week }\end{array}$ & $52.30 \%$ & 0.00 & $57.17 \%$ & 0.00 & $62.10 \%$ & 0.00 & $64.96 \%$ & 0.00 \\
\hline & 2 & $\begin{array}{l}\text { Removed by } \\
\text { municipality less } \\
\text { often }\end{array}$ & $2.35 \%$ & 0.05 & $1.59 \%$ & 0.04 & $1.59 \%$ & 0.04 & $1.58 \%$ & 0.05 \\
\hline & 3 & $\begin{array}{l}\text { Communal refuse } \\
\text { dump }\end{array}$ & $3.43 \%$ & 0.12 & $1.84 \%$ & 0.08 & $2.09 \%$ & 0.10 & $1.97 \%$ & 0.10 \\
\hline & 4 & Own refuse dump & $32.43 \%$ & 0.80 & $31.20 \%$ & 0.81 & $27.14 \%$ & 0.81 & $25.82 \%$ & 0.84 \\
\hline & 5 & No rubbish disposal & $9.49 \%$ & 1.00 & $8.21 \%$ & 1.00 & $7.08 \%$ & 1.00 & $5.66 \%$ & 1.00 \\
\hline \multirow{4}{*}{ Sanitation } & 1 & Flush or chemical & $50.47 \%$ & 0.00 & $55.21 \%$ & 0.00 & $59.42 \%$ & 0.00 & $65.88 \%$ & 0.00 \\
\hline & 2 & Pit latrine & $32.37 \%$ & 0.65 & $27.31 \%$ & 0.61 & $30.29 \%$ & 0.75 & $26.75 \%$ & 0.78 \\
\hline & 3 & Bucket latrine & $4.83 \%$ & 0.75 & $4.20 \%$ & 0.70 & $2.34 \%$ & 0.80 & $2.26 \%$ & 0.85 \\
\hline & 4 & $\begin{array}{l}\text { No sanitation } \\
\text { facilities }\end{array}$ & $12.33 \%$ & 1.00 & $13.29 \%$ & 1.00 & $7.94 \%$ & 1.00 & $5.10 \%$ & 1.00 \\
\hline \multirow{3}{*}{ Employment } & 1 & Employed & $58.24 \%$ & 0.00 & $50.84 \%$ & 0.00 & $60.97 \%$ & 0.00 & $57.04 \%$ & 0.00 \\
\hline & 2 & Inactive & $25.30 \%$ & 0.61 & $27.94 \%$ & 0.57 & $25.07 \%$ & 0.64 & $29.76 \%$ & 0.69 \\
\hline & 3 & Unemployed & $16.45 \%$ & 1.00 & $21.22 \%$ & 1.00 & $13.97 \%$ & 1.00 & $13.20 \%$ & 1.00 \\
\hline \multirow{5}{*}{ Education } & 1 & Above Matric & $8.23 \%$ & 0.00 & $9.47 \%$ & 0.00 & $11.14 \%$ & 0.00 & $13.73 \%$ & 0.00 \\
\hline & 2 & Matric & $13.54 \%$ & 0.15 & $17.14 \%$ & 0.19 & $15.92 \%$ & 0.18 & $25.74 \%$ & 0.30 \\
\hline & 3 & $\begin{array}{l}\text { Incomplete secondary } \\
\text { education }\end{array}$ & $40.70 \%$ & 0.59 & $37.05 \%$ & 0.60 & $43.76 \%$ & 0.67 & $38.85 \%$ & 0.75 \\
\hline & 4 & $\begin{array}{l}\text { Incomplete primary } \\
\text { education }\end{array}$ & $17.54 \%$ & 0.78 & $17.90 \%$ & 0.80 & $18.83 \%$ & 0.88 & $13.38 \%$ & 0.90 \\
\hline & 5 & No schooling & $19.98 \%$ & 1.00 & $18.44 \%$ & 1.00 & $10.35 \%$ & 1.00 & $8.30 \%$ & 1.00 \\
\hline
\end{tabular}

[I]: Share of total

[II]: Vertical weight 